\title{
Shier zitou jizhu (Collected notes on the twelve heads): A Recently Discovered Work by Shen Qiliang
}

MÅRTEN SÖDERBLOM SAARELA

Princeton University

Volume 12, 2014

The present paper will introduce a thus far unknown major work by Shen Qiliang 沈 啟亮 (fl. 1645-1693), Shier zitou jizhu 十二字頭集註 (Collected notes on the twelve heads; 1686), that I recently had the opportunity to read in its only known copy at the library of the National Museum of China (Guojia Bowuguan 國家博物館). The book's existence has previously been noted in catalogs, but inspection of the book itself reveals that it is much more than the published references to it suggest. Although retaining the structure of a syllabary, the book can equally be described as an elementary Manchu textbook for speakers and readers of Chinese, focusing on the pronunciation and writing of Manchu characters. The paper will give a detailed introduction of the book, including the available bibliographical information; a translation of the preface and the statement of editorial principles; and a description of the contents. Next, I will relate Shier zitou jizhu to other books. I will argue that the discovery of this work suggests that a work previously attributed to Shen might very well have been published without his involvement, with the implication that Shen might have died earlier than previously thought. I will also show how the influence of Shier zitou jizhu, despite only surviving in one known copy, can still be traced in Manchu syllabaries into the nineteenth century.

Mårten Söderblom Saarela 马腾

普林斯顿大学

本文所介绍的是一件由沈啟亮（活跃於 1645 至1693年）编写但却鲜有人知的 重要作品《十二字头集註》（1686）。笔者最近有机会得以阅读藏於中国国 家博物馆的该书孤本。本书过去曾经被列在目录上, 但是经详阅本书后, 会 发现其中所涵盖的资讯远比已出版的参考书中所开列的要来得丰富许多。本 书虽然维持了字母表的结构，但是也同样被描述為一本為汉语使用者所写的 
初级满语课本, 著重於满文字母的发音与书写。本文首先為该书提供了详尽 的介绍，包括了目前所知的书目资讯、序言与编辑凡例的译文，以及对目录 的描述。接著探讨《十二字头集註》与其他书籍的关联。笔者认為本作品的 发现暗示过去某部被认為是沈啟亮所写的作品可能在缺乏其参与的情况下出 版，这隐涵著沈啟亮的过世时间可能比吾人过去以為的还要来得更早。另外 笔者也将说明，即便《十二字头集註》该书如今海内仅存孤本，但其影响直 至19世纪仍旧能从满文字母表中追溯得出。

Mårten Söderblom Saarela 馬騰

普林斯頓大學

本文所介紹的是一件由沈啟亮 (活躍於1645至1693年) 編寫但卻鮮有人知的 重要作品《十二字頭集註》（1686）。筆者最近有機會得以閱讀藏於中國國 家博物館的該書孤本。本書過去曾經被列在目錄上，但是經詳閱本書後，會 發現其中所涵蓋的資訊遠比已出版的參考書中所開列的要來得豐富許多。本 書雖然維持了字母表的結構，但是也同樣被描述為一本為漢語使用者所寫的 初級滿語課本，著重於滿文字母的發音與書寫。本文首先為該書提供了詳盡 的介紹，包括了目前所知的書目資訊、序言與編輯凡例的譯文，以及對目錄 的描述。接著探討《十二字頭集註》與其他書籍的關聯。筆者認為本作品的 發現暗示過去某部被認為是沈啟亮所寫的作品可能在缺乏其參與的情況下出 版，這隱涵著沈啟亮的過世時間可能比吾人過去以為的還要來得更早。另外 筆者也將說明，即便《十二字頭集註》該書如今海內僅存孤本，但其影響直 至19世紀仍舊能從滿文字母表中追溯得出。

The present paper will introduce a thus far unknown major work by Shen Qiliang 沈 啟亮 (zi Hongzhao 弘照; fl. 1645-1693), ${ }^{1}$ Shier zitou jizhu 十二字頭集註 (Collected notes on the twelve heads; 1686), that I recently had the opportunity to read in its only known copy at the library of the National Museum of China (Guojia bowuguan 國家 博物館). The paper will give a detailed introduction of the book, including the available bibliographical information; a translation of the preface and the statement of editorial principles; and a description of the contents. Next, I will relate Shier zitou jizhu to

1. I would like to thank Chunhua 春花 of the National Palace Museum Library, Beijing, for helping me get access to Shen Qiliang's Shier zitou jizhu; Martin Heijdra for obtaining photocopies of Jianzhu shier zitou; and Susan Naquin, the anonymous reviewer, Brian Vivier, and Matthew Mosca for their helpful comments on different versions of this paper. Shen's dates are controversial. For the date of birth, I follow Kanda Nobuo 神田信夫, “Shen Ch'i-liang and His Works on the Manchu Language," in Proceedings of the Third East Asian Altaistic Conference, ed. Ch'en Chieh-hsien and Sechin Jagchid (Taibei: The Third East Asian Altaistic Conference, 1969), p. 130, who inferred the date from a mention in one of Shen's prefaces. Cf. the different dates proposed in Hayata Teruhiro 早田輝洋 and Teramura Masao 寺村政男, eds., Daishin zensho: Zōho kaitei, tsuketari Manshügo, Kango sakuin 大清全書: 増補改訂·附満洲語漢語索引 (Expanded and emended edition of Da-Qing quanshu, with appended Manchu and Chinese indexes) (Fuchū: Tōkyō gaikokugo daigaku Ajia Afurika gengo bunka kenkyūjo, 2004), 1: 1-3. My choice of the year 1693 as last known date that Shen flourished will be explained in the course of this paper. 
other books. I will argue that the discovery of this work suggests that a work previously attributed to Shen might very well have been published without his involvement, with the implication that Shen might have died earlier than previously thought.

Shen Qiliang has a special place in the history of Manchu studies. Author of the earliest extant dictionary of the Manchu language and compiler of the earliest collection of Manchu teaching material, his name appears in most treatments of the history of Manchu books and literature. ${ }^{2}$ Most importantly, Kanda Nobuo 神田信夫 (19212003) wrote an essay on Shen's life and work ${ }^{3}$ based largely on his own extensive bibliographical work in Manchu collections in Europe and the USA. ${ }^{4}$

Shen, son of a colonel in the Qing Army of the Green Standard and grandson of a civil official, was from the lower Yangzi region. He entered military service at an early age and served in the southeast for two years during the Rebellion of the Three Feudatories (1673-1681). In 1677, he moved to Beijing and embarked on the study of Manchu, living in the Banner section of the city and eventually working as a teacher. $\mathrm{He}$ later travelled to the south, but seems to have made a home for himself in the capital. ${ }^{5}$ Shen studied with several Manchu teachers. He first learned the Manchu syllabary in order to recognize single characters. From there he continued with strings of characters, which enabled him to read all kinds of writings. Although he found learning Manchu much more difficult than people had told him it would be, ${ }^{6}$ he seems to have enjoyed the advantage of learning Manchu embedded in a community of native speakers.

Kanda identified six published books by Shen: the pedagogical collection Qingshu zhinan 清書指南 (Guide to Qing writing; *1682, 1713); the dictionary Da-Qing quanshu 大清全書 (Complete book of the Great Qing; 1683, 1713); a compilation of bilingual excerpts: Sishu yaolan 四書要覽 (Essential readings from the Four books; 1686); bilingual editions of two common Chinese primers: Man-Han Qianziwen 滿 漢千字文 (The Thousand character essay in Manchu and Chinese; 1692) and Yuzhi

2. E.g., Pamela Kyle Crossley and Evelyn S. Rawski, "A Profile of the Manchu Language in Ch'ing History," Harvard Journal of Asiatic Studies 53.1 (1993): 83-87; Mark C. Elliott and James Bosson, "Highlights of the Manchu-Mongolian Collection," in Treasures of the Yenching: Seventy-Fifth Anniversary of the Harvard-Yenching Library, ed. Patrick Hanan (Cambridge, Mass.: Harvard-Yenching Library, Harvard University, 2003), pp. 83-84, 94-95; Evelyn S. Rawski, "Qing Publishing in Non-Han Languages," in Printing and Book Culture in Late Imperial China, ed. Cynthia J. Brokaw and Kai-wing Chow (Berkeley: University of California Press, 2005), pp. 314-15.

3. Kanda, "Shen Ch'i-liang."

4. Kanda Nobuo 神田信夫, “Ōbei genson no Manshūgo bunken” 欧米現存の満洲語文献 (Manchu documents currently held in European and American libraries), Töyō gakuhō 東洋学報 48.2 (1965): 70-95; Kanda Nobuo, "Present State of Preservation of Manchu Literature," Memoirs of the Research Department of the Toyo Bunko 26 (1968): 63-95. Kanda also drew on some then-recent bibliographical surveys: Ikegami Jirō 池上二郎, “Yōroppa ni aru Manshūgo bunken ni tsuite” ヨ 一ロッパにある満洲語文献について (On Manchu documents in Europe), Tōyō gakuhō 45.3 (1962): 105-21; Ikegami Jirō, “Yōroppa ni aru Manshūgo bunken ni tsuite (hoi)”ヨーロツパにある満洲語文献について(補遺) (On Manchu documents in Europe [supplement]), Tōoo gakuhō 東洋学報 47.3 (1964): 144-46.

5. Kanda, "Shen Ch'i-liang," pp. 130-31.

6. Shen Qiliang, ed., Qingshu zhinan 清書指南 Manju gisun-i jyinan (Guide to Qing writing), xylograph (1682, 1713), extant only as a supplement to the 2nd edition of Da-Qing quanshu (it carries no publication data of its own), “Zixu” 自 敘 (Author's preface), $1 b$. 
baijia xing Man-Han heji 御製百家姓滿漢合集 (Manchu-Chinese combined edition of the Imperially commissioned hundred surnames; 1693); and an annotated version of the Manchu syllabary, Jianzhu shier zitou 箋註十二字頭 (The Twelve heads, annotated; 1701).

However, since Kanda's research in the 1960s, the very substantial holdings of Manchu books in the PRC have slowly become catalogued, revealing a previously unknown work by Shen Qiliang, which will be the focus of this paper. Early efforts to catalog Manchu books held in China did not reveal the book's existence, ${ }^{7}$ which was first noted in the union catalog of Manchu holdings published in 1991, where it was listed as part of the collection of the library of the Museum of Chinese History (Zhongguo lishi bowuguan 中國歷史博物館), now the National Museum of China. The bibliographical précis reads:

$$
\begin{aligned}
& 0305 \text { 十二字头 } \\
& \text { juwan juwe ujui bithe } \\
& \text { 沈启亮 撰 } \\
& \text { 崇礼堂刻本 满文 } \\
& \text { 一册 } 21.7 \times 14.7 \mathrm{~cm}^{8}
\end{aligned}
$$

This précis is incorrect in so far as nowhere on the book is the Manchu title given as juwan juwe ujui bithe. The précis is, furthermore, misleading, as the book is not, strictly speaking, written in Manchu. The catalog entry gives the impression that we are dealing with a simple, monolingual Manchu syllabary, similar to other books with the title juwan juwe ujui bithe or any of its variants. ${ }^{9}$ However, not only is the work in fact bilingual; Chinese, not Manchu, is the predominant language.

7. Viz. Walter Fuchs, "Neues Material zur mandjurischen Literatur aus Pekinger Bibliotheken," Asia Major 7 (1932): 46982; Li Deqi 李德倁, ed., Guoli Beiping tushuguan, Gugong bowuyuan tushuguan Manwen shuji lianhe mulu 國立北平圖 書館、故宮博物院圖書館滿文書籍聯合目錄 (Union catalog of Manchu books in National Beiping Library and the National Palace Museum Library) (Beijing: Guoli Beiping tushuguan ji Gugong bowuyuan tushuguan, 1933); Walter Fuchs, Beiträge zur mandjurischen Bibliographie und Literatur (Tōkyō: Deutsche Gesellschaft für Natur- und Volkerkunde Ostasiens, 1936); Walter Fuchs, "Neue Beiträge zur mandjurischen Bibliographie und Literatur," Monumenta Serica 7.1-2 (1942): 1-37. Nor did Fengkuan’s 奉寬 (1876-1943) very valuable bibliographical notes, not published until much later (in Zhongguo kexueyuan tushuguan 中國科學院圖書館, ed., Xuxiu Siku quanshu zongmu tiyao (gaoben) 續修四庫全書 總目提要 (稿本) [Bibliographical summary of the Sequel to the Complete books of the four repositories (draft edition)] [Jinan: Qi-Lu shushe, 1996], written during 1931-1942), include a description of this work by Shen Qiliang. Kanda, who was unaware of the work's existence, had not examined Manchu holdings in Russia. However, no copy of the work has surfaced there, judging from my reading of the following catalogs: Hartmut Walravens, ed., Mandjurische Bücher in Rußland: Drei Bestandskataloge (Hamburg: C. Bell Verlag, 1986); Katō Naoto 加藤直人, “Roshia no Manshūgo shiryō” ロシアの満洲 語資料 (Manchu material in Russia), Manzokushi kenkyü tsüshin 満族史研究通信 6 (1997): 45-62; Tatiana A. Pang and M. P. Volkova, Descriptive Catalogue of Manchu Manuscripts and Block-prints in the St. Petersburg Branch of the Institute of Oriental Studies, Russian Academy of Sciences, Issue 2 (Wiesbaden: Harrassowitz, 2001).

8. Huang Runhua 黃润华 and Qu Liusheng 屈六生, eds., Quanguo Manwen tushu ziliao lianhe mulu 全国满文图书资料联 合目录 (Union catalog of Manchu material nationwide) (Beijing: Shumu wenxian chubanshe, 1991), p. 80.

9. E.g., the manuscript held at the Harvard-Yenching library with the call number MA5806.02/4130. 
Nevertheless, the précis from the union catalog was taken over almost tel quel in the catalog of Manchu books in the Beijing area, which was published in 2008, indicating that the book had not been inspected again for this catalog. ${ }^{10}$ Although the existence of the book could have been inferred from the above-mentioned catalogs, it has hitherto not been the object of scholarly study. ${ }^{11}$

\section{Contents of the Book}

Inspection of the book itself reveals that it is much more than the published references to it suggest. Although retaining the structure of a syllabary, the book can equally be described as an elementary Manchu textbook for speakers and readers of Chinese, focusing on the pronunciation and writing of Manchu characters.

The Manchu syllabary, ${ }^{12}$ the basis for Shen's book, consisted of two linear sequences of graphemes. The first sequence had been borrowed from the Mongols along with their version of the old Uighur script and subsequently modified by the addition of new graphemes. This sequence, which contained open syllables consisting of monophthongs with or without consonantal onsets, I will call the inner sequence. The second sequence was a Manchu invention and contained vowels or consonants acting as syllabic codas, as well as a zero coda. I will call this the syllabary's outer sequence. The syllabic codas included in the outer sequence, including the zero coda, were twelve in number, giving rise to the name "twelve heads" to refer to the syllabary. Every "head" consisted of the inner sequence paired with a coda from the outer sequence. In the first "head," the inner sequence was paired with the outer sequence's zero coda, meaning that the first "head" was coterminous with the inner sequence. The inner sequence typically contained 131 syllables, but as all possible combinations of the two sequences were not always listed in a given syllabary, the total number of syllables included varied somewhat,

10. The editors of this work only added the note that the measurements referred to the size of half a folio (one page): Beijing shi minzu guji zhengli chuban guihua xiaozu 北京市民族古籍整理出版规划小组, Beijing diqu Manwen tushu zongmu 北京地区满文图书总目 (Comprehensive catalog of Manchu material in libraries in the Beijing area) (Shenyang: Liaoning minzu chubanshe, 2008), p. 46.

11. The only reference to the work that I have seen in the literature also seems to be based only on the above-mentioned catalog entry, viz.: Chunhua 春花, “Qianlong chixiu Qinding Qing-Han duiyin zishi ji qi yingxiang” 乾隆敕修《钦定清汉对音 字式》及其影响 (Qianlong's imperially edited Qinding Qing-Han duiyin zishi and its influence), Lishi dang'an 历史档 案 2008.1: 55. This article correctly identifies the book as a Kangxi work, likely inferred from knowledge of the date of its author. However, it also identifies the publication as “at present the earliest known [Manchu syllabary]" 目前已知最早 的《十二字头》, a statement that would have been immediately recognized as incorrect upon inspection of the work's preface, which mentions Qingshu zhinan, an earlier—but not the earliest—collection also including a Manchu syllabary.

12. There is no comprehensive study of the Manchu syllabary. Descriptions of it from the point of view of language pedagogy and grammatology are found respectively in: An Shuangcheng 安双成, “Manwen shier zitou wo jian” 满文十二字头 我见 (My views on the Manchu twelve heads), in Manzu lishi yu wenhua 满族历史与文化, ed. Wang Zhonghan 王钟 翰 (Beijing: Zhongyang minzu daxue chubanshe, 1996), pp. 233-43; Louis Ligeti [Lajos], "À propos de l'écriture mandchoue," Acta Orientalia Academic Scientarum Hungarica 2 (1952): 235-302. 
while generally hovering around $1,400 .{ }^{13}$ The order of the inner sequence is irrelevant for the purposes of this paper. I will discuss the order of the outer sequence presently.

The contents of Shen's book can be summarized as follows. The cover page ([nei] fengmian ye [內] 封面頁) included the following pieces of information:

• The author: Shen Qiliang of Loudong 婁東 (viz. Taicang 太倉, Jiangsu);

• The author's relationship with the work: “Collector of notes" (jizhu 集註);

- The title in Manchu and Chinese: "The twelve heads" (juwan juwe uju; Shier zitou 十二字頭);

- And the name of the publisher: "Printed and published by Chongli tang" (Chongli tang zixing 崇禮堂梓行)..$^{14}$

The book has no running title in the page margins, but in the heading of the preface, it is called Shier zitou jizhu, "Collected notes on the twelve heads." I treat this as the work's full title. ${ }^{15}$

The book comprises twenty-eight folios. On some pages, the text next to the inner margin is illegible, since the book at some point seems to have been rebound with new string too far into the printed area of the page.

The book contains a preface ( $x u$ 序; 3 folios); some notes on "how to read the book" ( $d u f a$ 讀法, i.e. the equivalent of a "Statement of editorial principles" [fanli 凡例]; 1 folio); and twelve sections, each corresponding to one of the "heads" (24 folios).

The twelve sections are in turn composed of a note on the pronunciation of the syllables included in the chapter's section; the ca. 130 or fewer Manchu syllables that make up any given "head"; transcriptions into Chinese characters, placed next to the Manchu syllables; Manchu words and phrases containing a given syllable and their Chinese translations, placed beneath the Manchu syllables; and, finally, notes on the writing of the syllables included in the section, with examples ("Method of connecting characters," lianzi zhi fa 連字之法). In the first section, the notes on writing are more elaborate and have been divided into eight points. The first section is further anomalous in that it is followed by eighty-four Manchu transcriptions of Chinese syllables ("outer characters," waizi 外字). Inside the “heads," occasional circular reading marks have been added next to some Chinese characters in red ink.

13. This is the number given in Ligeti, "À propos de l'écriture mandchoue," 240-41. Moreover, the fact that the pairing of the inner and outer sequences did not produce all the syllables possible in Manchu compelled some writers of syllabaries to expand on this structure, causing further fluctuation of the total syllable count.

14. Except for the present book and Shen's Sishu yaolan, I know of no Manchu books published by Chongli tang. The publisher is not listed in Huang Runhua 黄润华, “Manwen fangke tushu shulun” 满文坊刻图书述论 (Account of commercial publishing in Manchu), Wenxian 文献 1999.2: 220-35.

15. The back outside cover, moreover, carries the manuscript title "The twelve heads from Qing writing, translated into Chinese, annotated by Shen Qiliang” 清文漢繹 [sic] 十二字頭, 沈啟亮註. As this title was added by hand to the back of the book—possibly by someone unfamiliar with Manchu books, which, unlike Chinese books, open from left to right-it is likely not original. 


\section{Preface}

The preface can be understood as subdividing into three sections: an initial section extolling the virtues of the twelve-headed syllabary-which is treated as coterminous with the Manchu script itself - and establishing its importance as a foundational text for learners of the language; a second section justifying its publication with an alleged previous lack of commercially published syllabaries and explaining the position of Shier zitou jizhu in relation to Shen's published œuvre to date and the nature of Shen's innovations to the syllabary; and a third and final long section on the nature of Manchu pronunciation and the need for the student to learn it in tandem with the elements of the script, as opposed to just picking up Manchu as a spoken language. This last section ends on an attempt to bridge the study of pronunciation with the study of grammar, which in turn is presented as service to the ruling dynasty.

The first section of the preface reads:

The book in twelve heads is the genera of the myriad words of Qing writing; applied to the translation of the classics and histories, they can be used in infinity, undergoing a thousand changes and myriad transformations. The twelve heads are also the equivalent of the Four books in Chinese literature: neither with regards to the meaning of grammatical particles [lit. "empty characters"], nor to the import of content words [lit. "full characters"], can one depart from this book. Then cannot it be said that if the reader is unclear with regards to one character within the twelve divisions [sc., the heads], then they will be hindered by that character? Likewise, if they are unclear with regards to the tracing of one character, then they will also misconstrue that character. If a student does not pay close attention to the basics [of Manchu writing], how could they ever succeed in appreciating its final products [sc., Manchu texts] ${ }^{16}$

The above description of the "twelve heads" capacity to produce an infinite amount of Manchu words, with which Shen opened the preface, is common to other texts of its genre. ${ }^{17}$

16. Shen Qiliang, Shier zitou jizhu 十二字頭集註 (Collected notes on the twelve heads), xylograph (Chongli tang, 1686), held at the library of the National Museum of China, $x u, 1 \mathrm{a}$ : 十二字頭之書，清文萬言之母也。其覾譯經史，而千 變萬化運用不窮; 猶如漢書中之一部四書虛字文義，不能出其書; 實字講論，不能出其書。蓋十二篇中， 有一字文理不明，則受一字文理不明之累；有一字點畫不明，則受一字點畫不明之誤；學者安可不謹其始 而克美其終也耶?

17. E.g., Liao Lunji 廖綸琖, Shier zitou 十二字頭 (The twelve character heads), in Zhengzi tong 正字通, facsimile of xylograph (1671; Beijing: Zhongguo gongren chubanshe, 1996), shier zitou yin, 3a: "a thousand changes and myriad transformations cannot exhaust [Manchu writing]” 千變萬化不可窮; Ling Shaowen 凌紹雯 and Chen Kechen 陳可臣, eds., Xinke Qingshu quanji 新刻清書全集 Ice foloho manju-i geren bithe (Complete collection of Manchu writing, newly cut), xylograph (Nanjing: Tingsong lou, 1699), fanli (1), 1a: "Through a thousand changes and myriad transformations, [Manchu writing] never leaves the scope [of the syllabary]” 千變萬化，不出範圍。 
The preface's second section is more interesting. Shen there mentions his earlier publications: Qingshu zhinan, Da-Qing quanshu, and what he refers to as Qingshu yilan. We know of no book by that name ever being published by Shen. The book as we know it is titled Qingshu yaolan, whose preface is dated to the 21st day of the 10th month of the 25th year of Kangxi (December 6, 1686), many months after the preface to Shier zitou jizhu. It cannot be excluded that Sishu yaolan represents the second edition of a work previously published under the title Qingshu yilan, which would have been lost since. The second section's assertion that commercially published syllabaries featuring pronunciation glosses thitherto had not been available suggests that Shen was unaware of the existence of Liao Lunji's 廖綸㙨 (n.d.) syllabary, published in Jiangxi in 1671. This would also help explain the idiosyncratic order of the "heads" in Shen's syllabary, to which I will return presently.

The second section of the preface reads:

I have previously printed Qingshu zhinan (The guide to Qing writing), which dealt specifically with the usage of grammatical particles; Da-Qing quanshu (Complete book of Qing writing), which assembled Manchu characters and their meanings; and Sishu yilan ${ }^{18}$ (The Four books at a glance), which explained the canonical tradition of translation. All the elements of the twelve heads comprise points where the method of pronunciation must be taught. Thus far, such teachings have not been available in the print shops, which has caused families to string them together and teach them in the household. I have now taken the twelve heads and glossed their sounds using Chinese characters, matching each [Manchu] character with a sound [gloss]. Where there is no corresponding sound in Chinese, I have added circles, based on the even, rising, departing, and entering tones [that I impute to the Manchu sound], by which they should be read. You will naturally comprehend and assimilate it; do not let the minute [differences in pronunciation that might exist between the Manchu character and the Chinese gloss] tie you down. ${ }^{19}$

We also here see Shen explaining that he has added Chinese pronunciation glosses to the Manchu and instructing the reader with regards to their use. Shen's declaration that he has "added circles, based on the even, rising, departing, and entering tones, by which they should be read” 借平上去入之音, 圈着念去 is hard to understand. Circles placed at one of a character's four corners were commonly used in phonological texts

18. Sic: no work by Shen with this title has survived.

19. Shen, Shier zitou jizhu, xu, 1a-b: 余前刊有『清書指南』一書，專講虛字用法; 又『大清全書』一書; 乃彙集 滿洲字義; 又『四書一覽』一書, 乃啟眽譯之宗傳。所有十二字頭之根本, 內有讀法必授之處, 尚未刊 布坊間, 使家絃而戶曉之。余今以十二字頭, 音釋漢字, 俱一字一音, 如無對準之漢音, 即借平上去入之 音，圈着念去; 自然心會而神通，不錯絲毫矣。In quotations from Shen's book I have tried to keep all variant characters, rather than substituting the expected standard forms. 
to indicate that the character in question was to be read differently than expected. ${ }^{20}$ In Shier zitou jizhu, some characters have small circles in the upper-right corner or in the lower-right corner. For example, the phrase wao-weo-fio is glossed as $f u$ 縛。 [in the upperright corner] $f u$ 覆。 [in the upper-right corner]_fou 否, and the phrase foo-fuo-fúo is glossed $f u$ 浮。 the lower-right corner] $-f o u$ 否-fu 浮, ${ }^{21}$ where the presence of a circle is clearly intended to give the same character two separate readings. ${ }^{22}$ Although the Roman transcription presents the difference between $o$ and $\hat{u}$ as one in vowel quality or length, there is evidence that Chinese people in the Qing thought of it as a difference in tone. Notably, Shen's contemporary Xiong Shibo 熊士伯 (fl. 1672-1709) said that "Manchu pronunciation does not distinguish the four tones, thus the rhyme of the $\hat{u}$ character is not frequently used," ${ }^{23}$ implying that $\hat{u}$ was associated with distinctions of tone. That might also have been how Shen thought of the differences between the Manchu syllables foo and füo, which might help explain the reference to the four tones in Shier zitou jizhu's preface.

Moreover, in cases where one Manchu syllable is transcribed using two Chinese characters, the pair of Chinese characters transcribing the last Manchu syllable in a three-syllable phrase often has a small filled-in circle between them. ${ }^{24}$ As no further instructions were given, it is unclear whether the phrase "circling" (quanzhe 圈着) referred to either — or both—of these types of circles. I will return to this point presently.

The third and longest section of Shen's preface touches on several points. Shen here makes use of technical vocabulary from the Chinese discipline of phonology to characterize Manchu pronunciation. However, the understanding of this section of the preface is complicated by, on the one hand, Shen's use of one word in several distinct senses in the same text and, on the other, his idiosyncratic use of words with established, different meanings. In the preface's third section, the term gunshe 滾舌 is the best example of the former: Shen seems to use it both as a general reference to the articulations needed to properly pronounce Manchu, as well as a technical phonological term describing the pronunciation of the consonant $r$, which posed particular difficulty for Chinese-speaking learners of Manchu. ${ }^{25}$ The clearest example of the latter is Shen's

20. E.g., Lao Naixuan 勞乃宣, Dengyun yide 等韻一得 (Quick introduction to graded rhymes), xylograph, Juzhai suoxue (Wuqiao guanxie, 1898), vol. 1, neipian, 1b-2a, where some characters have circles in their lower-left corners.

21. Shen, Shier zitou jizhu, shier zitou, 13a.

22. One might also ask why Shen would include these syllables at all in the syllabary, since many of them are not native Manchu syllables and do not appear to be regular transcriptions of Chinese. Perhaps Shen's interest in phonology compelled him to include theoretically possible but in reality unattested syllables in his list. It should also be remarked that the syllabary even in its most simple state included many syllables that were rare and possibly even unknown in the Manchu vocabulary. Thus alphabetically arranged Manchu dictionaries in general used a reduced version of the syllabary's inner sequence to arrange their lemmata.

23. Xiong Shibo 熊士伯, Dengqie yuansheng 等切元聲 (The fundamental sounds cut in grades), facsimile of xylograph, Siku quanshu cunmu congshu: jingbu vol. 219 (1709; Jinan: Qi-Lu shushe, 1997), partially illegible.

24. E.g., Shen, Shier zitou jizhu, shier zitou, 14a: bar-ber-b[i]r八勒百勒必. 勒 (with “” representing the filled-in black circle).

25. The difficulty of $r$ is indicated by Qing pedagogues' need to explain its varying transcription and articulation, e.g., ManHan ziyin lianzhu shiwen 滿漢字音聯註釋文 (Character pronunciations, linked annotations, and textual explanations in 
use of zhengyin 正音 — a term that in Qing writings on language usually referred to an ideal standard of pronunciation ${ }^{26}$ - in reference to the internal sequence of the "twelve heads." The third section reads:

If the beginning students are Manchus, then they will know Manchu pronunciation and the tongue's movements [gunshe] natively. If the students are not Manchus, then they will not know the sounds and they will think the tongue's movements difficult. However, the tongue's movements in Manchu will easily be gathered from the main sounds [zhengyin, viz. the inner sequence of the syllabary]. The student must know that the method of moving the tongue has a fixed and natural internal logic to it. With effort it will be attained, and the student will produce the tongue's movements without thinking about it. Aspiring students who are not Manchus do not have to rigidly adhere to the Manchu movements of the tongue and let that hurt their motivation to study. All they have to do is to take the twelve heads, look at the Manchu characters and read, recite, write, and think about them until they feel completely familiar. Completing these four operations to the point of complete familiarity is the secret key to the tongue's movements, which [in turn] opens up the subtleties of Manchu pronunciation.

Those students, who want to master Manchu pronunciation straight away and discard these four operations and proceed directly to the study of the tongue's movements, will use the following argument:

"A long time ago, Confucius was born in Lu. Those in the realm who wanted to read his writings first had to learn the local pronunciation of the land of Lu before they could chant his poetry and read his writings. If they did not first learn the sounds of $\mathrm{Lu}$, their pronunciation would not match [what Confucius intended], and the writings would be difficult to read."

Alas! It goes without saying that these words cannot be believed. Do the people who use this argument not know that, once the student has learned the Qing characters, they will also have learned the Manchu pronunciation? That once they have mastered the principles of writing, the tongue's movements come naturally? They should try to read the $a$ head until it rolls off the tongue with ease, and they will know that this head constitutes the main sounds. Having similarly read [the other heads], they will know that the $a i$ head is a sound in the back of the mouth [yanyin]; that the an head is a nasal sound [biyin]; that the ang head is a palatal nasal [ebi yin]; that the ao head is a throat sound [houyin]; that the ar head is a trilled sound [gunshe yin]; that the $a k$ head is a tongue-root sound [shegen yin]; that the as head is a anterior dental sound [chiyin]; that at is a sound with the tongue kept straight inside the mouth [neizhi yin; alveolars, viz.

Manchu and Chinese), chirograph held at Dalian Library with the call number M22-149, likely finished in 1861-1875, vol. 1, “San pian” 㕘篇 (no pagination), jingle beginning with Han yong 'er' $z i$ 漢用爾字.

26. Geng Zhensheng 耿振生, Ming-Qing dengyun xue tonglun 明清等韵学通论 (Comprehensive discussion of Ming-Qing rhyme table learning) (Beijing: Yuwen chubanshe, 1992), pp. 117-26. 
pronounced with the tip of the tongue pointed straight towards the back of the upper front teeth]; that $a b$ is a pinched-mouth sound [cuokou yin, viz. produced with the lips closed]; that $a l$ is a rolled-tongue sound [juanshe yin]; and that am is a closed-mouth sound [bekou yin].

Among the sounds above, the trilled sound [gunshe zhi yin] is most important, for this trilled sound carries the distinction between perfective [yiran] and imperfective [weiran] aspect. However, it is not a difficult thing: simply by reading enough texts, you will master the perfective aspect, by which you will know the characters $k a$ ga $h a$, and the imperfective aspect, by which you will know the characters ra re ri. Then these movements of the tongue will all come naturally. Let us imagine a student who has not familiarized himself completely with the texts and who has not made sense of the principles, but only laboriously learned the tongue's movement [gunshe] and the pronunciation of Manchu. Although such a student would know that the tongue would move so well that it would bat like the vanes of a wind wheel and pronounce Manchu as exquisitely as the five sounds and six pitch pipes [of ancient music], what good would it do for the transmission of age-old sayings or the essays of the translation examinations? Rather, future students should apply themselves to first cultivate the basics of Manchu and carefully ascertain its meaning, in order to develop the uniform script [tongwen 同文] that our Sagacious Son of Heaven created to illuminate countless generations. In the higher realm, it facilitates the state in transforming the people and ameliorating their customs. In the lower realm, it allows the student to cultivate himself in order to govern others. Although these words stem from my own humble self, they might perhaps still be of some use to you.

Preface written by Shen Qiliang of Loudong in the 1st month of the 25 th year of Kangxi [1686]. ${ }^{27}$

27. Shen, Shier zitou jizhu，xu，1b-3b: 抑初學者，若係滿洲，則有本來之滿音，有本來之滾舌; 若非滿洲，則無 其音, 而難其滾舌矣。然滿音滾舌不過正音之餘事耳。要知滾舌之法有固自然之一理在內, 功到渠成; 其 滾舌不欲滾而自滾者也。今之學者若非滿洲, 可不必拘泥在滿音滾舌之上, 以難其向學之心思; 只要將十 二字頭, 照字熟讀, 熟背, 熟寫, 熟思; 此四個熟字, 即便是得滾舌之秘法, 領滿音之微妙矣。若舍此四 個熟字, 乃先欲正滿音, 先學滾舌, 以此論之: 「昔孔子生於魯, 而天下之人, 欲讀其書者, 必該先學魯 地之土音; 然後可以誦其詩, 讀其書, 不然, 則音不對; 書難讀也。」噫嘻! 其言之不足信也; 不待言而 可知矣。殊不知夫清字既熟? 而滿音自曉, 文理既通, 而滾舌自便乎? 試將 $a$ 字頭讀得滾熟, 即知其爲正 音也; $a i$ 字頭讀得滾熟, 即知其爲咽音也; $a n$ 字頭讀得滾熟, 即知其爲鼻音也; ang 字頭讀得滾熟, 即知 其爲䶖 [The original has [月鹿]. This character looks similar to chun 脣, “lips,” which makes little sense in this context. I amend it to $e$ 䶜, “palate.”] 鼻音也; $a o$ 字頭讀得滾熟。即知其爲喉音也; $a r$ 字頭讀得滾熟, 即知其爲滾 舌音也; $a k$ 字頭讀得滾熟, 即知其爲舌根音也; $a s$ 字頭讀得滾熟, 即知其爲齒音也; $a t$ 字頭讀得滾熟, 即 知其內直音也; $a b$ 字頭讀得滾熟, 即知其爲撮口音也; al 字頭讀得滾熟, 即知其爲卷舌音也; em [Sic: read $a m$ for $\mathrm{em}$.] 字頭讀得滾熟; 即知其爲合口音也。已 [Sic: read $y i$ 以 for $y i$ 已.] 上諸音, 惟滾舌之音爲要; 其滾 舌之音, 有已然未然之文義在內故耳。然而非難也：只要書讀得熟, 理會得通; 已然者, 即知 $k a g a h a$ 等 字; 未然者, 即知 r a r e r i 等字; 斯滾舌皆出於自然矣。假使學者書未曾讀熟理未曾講明, 苦苦的单學會了 滾舌，苦苦的单學會了滿音，而滾舌雖熟似風輪轉轆，滿音雖妙似五聲六律，亦何補於千古之陳言，眽譯 之考文哉? 顧後之學者務先崇其本，深心考義，以闡我聖天子創造之同文; 昭垂萬世，益以上佐國家化民 成俗，下爲學者脩已治人。斯言也，竊比之意，則未必無小補云。康熙二十五年丙子正月壬辰婁東沈啟亮 序。The date given using the sexagenary cycle does not add up: the 25th year of Kangxi was the bingyin year and not the bingzi year, which was the 35th year of Kangxi (1696); in neither year did the 1st month contain a renchen day. I 
Shen's stress on the pronunciation of Manchu is interesting for two reasons. First, it contrasts with Liao Lunji's comparable pedagogical exhortation from a few decades earlier. Whereas Liao had criticized the habit of learning how to write without learning how to pronounce Manchu, ${ }^{28}$ Shen seems to be criticizing those who are content with trying to learn Manchu through osmosis or assimilation in a Manchu speech community. Perhaps this difference reflects Shen's situation in Beijing, where Manchu at this time was a spoken language. Second, Shen's invocation of phonological vocabulary to describe the pronunciation of Manchu does not seem to stem so much from pedagogical necessity as from a will to assimilate the new language into a familiar conceptual framework. Shen identifies each of the "heads" with a particular articulation. This seems very forced, however, as the characteristics of the sounds' articulation varyingly include either the place or the mode of articulation in a way suggesting that Shen's main concern is to make the number of identified articulations match the number of codas in the "twelve heads."

Lastly, Shen's attempt to bridge the study of pronunciation and grammar is focused on grammatical phenomena he previously discussed elsewhere. ${ }^{29}$ The final linking of the study of Manchu to the dynastic ambition of tongwen is also legion in other texts of this genre. The term tongwen and its changing meaning in the Qing period deserve a study of their own. Here, I have rendered it according to the established translation of its locus classicus: the Doctrine of the Mean. ${ }^{30}$

\section{Shen on How to Read the Book}

Four points comprise the statement of editorial principles. The first of these points instructs the reader to read aloud all of the "twelve heads" in the order they appear. It reads:

1. How to read the text. First, take careful note of the instructions [on pronunciation] beneath the word hergen, a "written character" that begins every chapter [e.g., the phrase a e $i$ sere hergen, "the characters pronounced $a-e-i$," which is the heading for the first "head"], then recite the given chapter. When you look at a Qing character, your mind should be with the [corresponding] Chinese character; when you look at

have followed the numerical date (Kangxi 25) over the sexagenary date on the basis of internal evidence: whereas Shen in the preface counts among his published works those that appeared before or in 1686, he made no mention of the works published after that date.

28. Liao, Shier zitou, shier zitou yin, 2a-b.

29. Shen Qiliang, Da-Qing quanshu 大清全書 Daicing gurun-i yooni bithe (Complete book of the Great Qing), facsimile of xylograph (1683; Shenyang: Liaoning minzu chubanshe, 2008), fanli, 2a.

30. Andrew H. Plaks, trans., Ta Hsüeh and Chung-yung: The Highest Order of Cultivation and On the Practice of the Mean (London: Penguin, 2003), pp. 92-93. 
a Chinese character, your mind should be with the [corresponding] Qing character. When you have understood the Qing characters, whenever you see Chinese characters, think about how what the equivalent Qing expression would be; whenever you see Qing characters, think about what the equivalent Chinese expression would be. ${ }^{31}$

The second point stressed the importance of Manchu onomatopoeia found in the book, which occur among the vocabulary items occasionally listed beneath the syllables in the "heads." The onomatopoeia are structured like the following expression, listed under the syllables $k \hat{u}-g \hat{u}-h \hat{u}$ in the first "head":

kûwak cak seme, "noise" (xiangsheng 响声). ${ }^{32}$

Where kîwak cak is the onomatopoeia. The second point referred to these expressions:

2. The set phrases including the word seme, "saying" —all relatively strongly descriptive words - contain the essentials of the expression's meaning. You should memorize every character of such expressions. ${ }^{33}$

The third point deals with an aspect of Shier zitou jizhu that in retrospect appears as one of its most noteworthy characteristics: Shen's use of nonsensical combinations of Manchu characters to illustrate their changing shapes depending on their placement at the beginning, in the middle, or at the end of a word. For example, in the eight-point notes on writing that succeeds the first "head," Shen offered the following instruction:

[The first "head"] contains the characters ba bi bo pa pi po sa so so la lo ma mo ca co ya $y o$. If we connect these seventeen characters and write them together, we get babibopa piposasošolalomamocacoyayo. ${ }^{34}$

This kind of instruction on writing involves abstracting the Manchu script from the Manchu language, allowing that it can record sounds that are not only without any semantic content whatsoever, but border on the unpronounceable. We do not find anything quite like these nonsensical combinations in other Manchu textbooks. The third point explains the purpose of such character combinations:

31. Shen, Shier zitou jizhu, dufa, 1a: 一、讀法: 每篇先將首向 hergen 之下, 細註詳認明白, 然後通篇朗誦; 如眼 看清字, 心在漢字; 如眼看漢字, 心在清字; 如清字既明之後, 遇着漢文, 則思其清文作如何說; 遇着清 文，則思其漢文作如何說。

32. Ibid., shier zitou, 1a.

33. Ibid., dufa, 1a: 一、句下細註成語 seme 等字, 俱係槶譯中比量形容之詞; 乃文義中之最要者, 宜當字字記 熟。

34. Ibid., shier zitou, 3b: 有 ba bi bo pa pi po sa so šo la lo ma mo ca co ya yo。 此十七字連寫在一處者則 babibopapiposasošolalomamocacoyayo 也。 
3. At the end of every chapter there are detailed instructions on how to connect characters into words. These instructions, grouping seven, eight, or even ten or more characters together, are intended to give a taste of how Manchu characters are actually written; they are devoid of meaning and cannot be used in real language. You should not ignore them just because they do not form real words, but verify their structure character by character. ${ }^{35}$

The fourth and last point of the statement of editorial principles deals with the sixth Manchu vowel $\hat{u}$. This vowel, written with a grapheme borrowed from Mongolian, where it denotes the front vowels $\ddot{o}$ and $\ddot{u}$, was often written as $o$ in unreformed Manchu. Its pronunciation has been the subject of some debate. According to Ferdinand Verbiest (1623-1688), an older contemporary of Shen, $o$ and $\hat{u}$ "are distinguished only in Tartar writing, and not in pronunciation." ${ }^{36}$ Shen likewise seems to have considered the two characters as graphic variants identical in pronunciation. He explained the existence of $\hat{u}$ in the vowel series by the desirability of arranging syllables in groups of three. The separation of syllables into groups was standard in Manchu syllabaries of the Qing period and had an analog in the structure of Chinese primers. ${ }^{37}$ The fourth point reads:

4. When the twelve heads were first parsed, the phrases containing the characters $0-u-\hat{u}$ only contained the two characters $o$ and $u$. Later, because these phrases were too short, the character $\hat{u}$ was added in order to complete the rhyme. It was not, as some would have us believe, the addition of a different character. Nowadays, some readers take them as three [different] characters and pronounce them as [three] different sounds, which really goes against the original intention of completing the rhyme. Now, in cases where two characters have the same pronunciation, the Chinese characters added to the side to serve as a pronunciation gloss for the first character will serve also to gloss the second character. The perceptive reader should not mistake this for an error on my part. ${ }^{38}$

After the four points on how to read the book follows the main body, divided into

35. Ibid., dufa, 1a-b: 一、每篇後, 細講連字之法, 尤宜細玩: 又有七八字, 或十数字連寫在一處者, 俱係不成 話不成句之詞; 獨爲初學者, 認連字之法也。須當按字確認, 不可因其不成話而忽之。

36. [Ferdinand Verbiest], Elementa lingua tartarica (Rudiments of the Tartar language), ed. Melchisédech Thévenot, written in 1677-1678 (1686; Paris: Thomas Moette, 1696 [fourteen years passed between printing and publishing]), p. 5: diversitatem tantùm exhibere in littera Tartarica, nullam in pronunciatione.

37. For the often rhymed syntactic units of two, three, or more syllables in Chinese primers: Zhang Zhigong 张志公, Chuantong yuwen jiaoyu chutan (fu mengxue shumu gao) 传統语文教育初探 (附蒙学书目稿) (First forays in traditional literacy education [with a draft bibliography of primers appended]) (Shanghai: Shanghai jiaoyu chubanshe, 1962), pp. 75-77.

38. Shen, Shier zitou jizhu, dufa, 1b: 一、十二字頭之句讀, 始作之者, 其 $o u \hat{u}$ 等句, 原止有 $o u$ 二字; 後因句讀 太促, 故添一 $\hat{u}$ 字在下, 以親貼口韻耳; 並非添一他字之說。今有讀者, 或以三字而讀三音; 此甚非始作 貼韻之本意也。余今音釋漢字在傍如下一字, 與上一字同者, 即以上一字之音音之; 高明者, 勿以我爲誤 釋焉。 
twelve sections, one for each of the syllabary's "heads," each having the structure outlined above.

\section{Relationships to Other Books}

Several features of Shier zitou jizhu invite comparison with similar books. Like Liao Lunji's syllabary, the Manchu syllables are glossed using Chinese characters, and like Da-Qing quanshu, it contains dictionary entries consisting of Manchu words and phrases with Chinese translations. Although the dictionary entries are similar to the corresponding entries in Shen's dictionary, they are not identical. ${ }^{39}$ The Chinese pronunciation glosses, furthermore, are different from those in Liao's syllabary, as well as from those in the next syllabary known to have appeared in print. ${ }^{40}$ This supports Shen's claim in the preface that he was the originator of the pronunciation glosses.

Shier zitou jizhu is also different from the two other syllabaries held to have been printed by Shen: the "twelve heads" included in Qingshu zhinan, predating the present work, and Jianzhu shierzitou, the last known work to have appeared under Shen's name. ${ }^{41}$ As many scholars have noted, the order of the "heads" in the Qingshu zhinan syllabary differs from the conventional order as represented by Liao Lunji's syllabary and all other known syllabaries (excluding those printed by Shen). As the following table shows, the order of Shen's two syllabaries differs substantially from the conventional order. Shen's two syllabaries in turn differ in the ordering of the "heads" in $-t$ and $-s$.

The differences in the order of the "heads" are hard to explain. As I mentioned, it is reasonable to assume that Shen was unaware of Liao's syllabary. However, both Liao and Shen separately noted that simple Manchu syllabaries without pronunciation glosses had been available in print for a long time. ${ }^{42}$ Either the order of the syllabaries available to Shen differed from that found in all other Qing syllabaries, which is unlikely, or he found the order insignificant, which would explain why he would allow the order to differ between Qingshu zhinan and Shier zitou jizhu. However, given the fact that Shen organized his dictionary around a specific order of the syllabary, this possibility also seems very unlikely. There remains the possibility that Shen intended for the order of Shier zitou jizhu to conform to Qingshu zhinan, the order of which is also followed in

39. Cf. Shen, Shier zitou jizhu, shier zitou, 1b: so 皮膚村處。牛脖肛子。言必中口。胡抛撒米狠。Hayata and Teramura, Daishin zensho, vol. 1, 0714a2: so 皮膚村處。牛脖肛子。胡抛撒米狠戻也。言必中口。言語靈應。醋。

40. Liao, Shier zitou; Ling and Chen, Xinke Qingshu quanji.

41. Naturally excluding the second, unrevised printing of Da-Qing quanshu in 1713, which might very well have happened without Shen's involvement.

42. Liao, Shier zitou, shier zitou yin, 4b (referring to “state school xylographs" [guanxue keben 官學刻本]); Shen, Da-Qing quanshu, $x u, 2 \mathrm{~b}$ (referring to syllabaries that have “long been available in the print shops” 久有梓布坊間). 


\begin{tabular}{ccc} 
Conventional Order: & Qingshu zhinan: & Shier zitou jizhu: \\
\hline $1 .-\emptyset$ & $1 .-\emptyset$ & $1 .-\emptyset$ \\
$2 .-i$ & $2 .-i$ & $2 .-i$ \\
$3 .-r$ & $3 .-n$ & $3 .-n$ \\
$4 .-n$ & $4 .-n \bar{g}$ & $4 .-n \bar{g}$ \\
$5 .-n \widehat{g}$ & $5 .-0$ & $5 .-o$ \\
$6 .-k$ & $6 .-r$ & $6 .-r$ \\
$7 .-s$ & $7 .-k$ & $7 .-k$ \\
$8 .-t$ & $8 .-t$ & $8 .-s$ \\
$9 .-b$ & $9 .-s$ & $9 .-t$ \\
$10 .-0$ & $10 .-b$ & $10 .-b$ \\
$11 .-l$ & $11 .-l$ & $11 .-l$ \\
$12 .-m$ & $12 .-m$ & $12 .-m$ \\
\hline
\end{tabular}

Shen's dictionary, but that it got confused during printing. The printing of Shier zitou jizhu is indeed of poor quality, showing many mistakes in the rendering of the Manchu characters.

The discovery of Shier zitou jizhu also raises questions with regards to Jianzhu shier zitou, the syllabary that Kanda Nobuo found represented by an incomplete copy held in the Apostolic Library in the Vatican. ${ }^{43}$ In the following, I will briefly introduce this work and relate it to Jianzhu shier zitou.

The Vatican copy carries the seal of "J. G. Schwarz, Consul of the United States of America at Vienna," a position he held between 1830-1853. ${ }^{44}$ The title page further carries a big round seal without any writing, depicting a flower. On the back of the book, there is a paper slip with the brush-written name Bonadiduo 伯納弟多, probably a Chinese transcription of Benedicto. This might have been the name of a European missionary who would have initially acquired the book in China in the eighteenth or early nineteenth century, before it came in the possession of Schwarz.

Most of the information on the cover page is given in Chinese with Manchu transcription. The syllabary is said to have been "collated and corrected" (jiaozheng 較正, where jiao 較 stands for jiao 校, a common practice among commercial publishers since the late Ming $)^{45}$ by Shen Qiliang. The page further carries the location and name of the publisher; the note "new engraving free from errors" (xin juan wu cha 新鐫 無差), which indicates that this was a commercial printing; and the secondary title Zengbu Manzhou zahua 增補滿洲雜話 (Augmented miscellaneous Manchu phrases).

43. Kanda, "Present State of Preservation," p. 89; Kanda, "Shen Ch'i-liang," p. 129; Giovanni Stary, Opere mancesi in Italia $e$ in Vaticano (Manchu works in Italy and the Vatican) (Wiesbaden: Harrassowitz, 1985), pp. 41-42; Yao Xiaoping 姚小 平, “Fandigang tushuguan suocang ruogan Ming-Qing yuyan wenzi shu” 梵蒂冈图书馆所藏若干明清语言文字书 (Some Ming-Qing books on language and writing held in the Vatican Library), Yuyan kexue 语言科学 5.6 (2006): 103-4. 44. Adelaide R. Hasse, Index to United States Documents Relating to Foreign Affairs, 1828-1861, in Three Parts, Part III-R to $Z$ (Washington, D.C.: Carnegie Institution of Washington, 1921), p. 1462.

45. Soren Edgren, personal communication (2012). 
The book includes a preface; the syllabary and the miscellaneous phrases; Shen Qiliang's name and the date of writing; and some manuscript annotations spread throughout the volume. One folio, comprising most of the seventh "head," is missing. Unlike the syllabaries in Qingshu zhinan and Shier zitou jizhu, the "heads" in Jianzhu shier zitou are in the conventional order.

The layout of the main body of the book can be called “joint-faced” (hebi 合璧) in the old, Ming sense of the word: the page had an upper and a lower section, with two texts running parallel to each other across the pages. ${ }^{46}$ The book was also "jointfaced" in the sense familiar from later bilingual Qing books, with alternating lines of Manchu and Chinese text together sharing the entirety of the page, as the Manchu syllables, similarly to the presentation in Liao Lunji's syllabary, were accompanied by Chinese-character transcriptions. The pronunciation glosses differ from those in Shier zitou jizhu.

In Jianzhu shier zitou, the upper section contained the miscellaneous Manchu phrases, whereas the much larger lower section contained the syllabary. The layout, reminiscent of Ming prints, shows this syllabary as belonging to the hesitant, early phase of commercial Manchu publishing, before the appearance of Manchu books became more or less standardized. ${ }^{47}$ Although the Manchu and Chinese text occupies different parts of the page in Shen's Man-Han qianzi wen, none of his other books have two completely different texts running concurrently across the pages.

As Kanda Nobuo intuited, Jianzhu shier zitou underwent several editions among the Beijing publishers into the second half of the nineteenth century. ${ }^{48}$

Although the cover page identified Shen as the author of Jianzhu shier zitou, the preface is not signed by Shen, but consists of a single page quotation attributed to him:

Shen Hongzhao [sc. Qiliang] says: "The reading of Chinese books begins with The Four Books, and the practice of Manchu texts begins with the twelve character heads. If you are thoroughly familiar with the twelve character heads, which are the basis of learning, then reading connected characters [i.e., words] will present no problems, and there will be nothing to slow you down when reading the names of persons and clans in the archival records.

However, within [the twelve heads] there are nasal sounds [biyin], throat sounds [houyin], anterior dental sounds [chiyin], sounds with a straight tongue [zhishe yin;

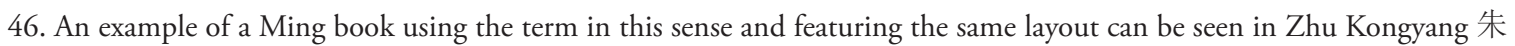
孔陽, Xinke Ruizhang xuan dingzheng ziyun hebi 新刻瑞樟軒訂正字韻合璧 (Newly cut joint-faced character rhymes corrected in the Auspicious Camphorwood Studio), facsimile of the xylograph held at the Hunan Provincial Library, Siku quanshu cunmu congshu: jingbu, vol. 199 (1628; Jinan: Qi-Lu Shushe, 1997).

47. The development of page layout in Manchu printed books is discussed in Walter Fuchs, "Miszellen zu MandjurischChinesischen Drucken," Zentralasiatische Studien 5 (1971): 121-26.

48. Kanda, "Shen Ch'i-liang," p. 140. 
alveolars], closed-mouth sounds [hekou yin], rolled-tongue sounds [juanshe yin], and pinched-mouth sounds [cuokou yin]. In [the twelve heads,] the trilled sound [gunshe $y i n$ is most important to practice to mastery. The beginning student will benefit from referring to the Chinese characters - the explanations to the side [of the Manchu] while abiding the rhymes of the capital. A small circle has been added to the corner of the character wherever the pronunciation of an original [Manchu] character could not be matched [by a Chinese character], so as to distinguish the essentials of the even, rising, departing, and entering [tones]; just try to avoid the error of mixing up [the sounds]." ${ }^{9}$

The preface to Jianzhu shier zitou reads like a corrupted paraphrase of parts of the preface to Shier zitou jizhu. Like Shier zitou jizhu, Jianzhu shier zitou began by setting up the "twelve heads" as an analogue to the Four Books as the basis of Manchu education. Second, it classified the types of sounds found in the Manchu syllabary, again similarly to the preface of Shier zitou jizhu.

Shier zitou jizhu had identified "sounds in the back of the mouth" (yanyin); nasals (biyin); palatal nasals (ebi yin); "throat sounds" (houyin); trills (gunshe yin); "tongue-root sounds" (shegen yin); "anterior dental sounds" (chiyin); "sounds with the tongue kept straight inside the mouth" (neizhi yin); "pinched-mouth sounds" (cuokou yin); "rolledtongue sounds" (juanshe yin); and "closed-mouth sounds" (hekou yin). Jianzhu shier zitou, by contrast, identified only eight sounds. Of Shier zitou jizhu's eleven sounds, it retained seven: nasals, "throat sounds," "anterior dental sounds," "closed-mouth sounds," "rolled-tongue sounds," "pinched-mouth sounds," and trills. The eight sound types, the "sounds with a straight tongue," was furthermore similar to Shier zitou jizhu's "sounds with the tongue kept straight inside the mouth."

Finally, the preface to Jianzhu shier zitou added a note explaining the function of the circles that had been added to indicate that a character should be pronounced differently in two cases. These circles-rather, drop-shaped marks-are, as the preface makes clear, found in the upper-right corner of a character. However, they do not seem to have much to do with the tone of a character: in the first "head," they are used to distinguish the transcription of two different Manchu initials. ${ }^{50}$ Although these diacritic marks are not identical in Jianzhu shier zitou and Shier zitou jizhu, it is clear that this passage in the former's preface is based on the corresponding passage in the latter, which I discussed above.

49. Shen Qiliang, Jianzhu shier zitou 箋註十二字頭 Giyan ju si el dz teo (The twelve heads annotated), xylograph (Beijing: Fukui zhai, 1701), incomplete copy held at the Vatican Apostolic Library with the call number BORG. CINESE 351.7, 1a: 沈弘照曰：「讀漢書由『四書』; 習滿文由十二字頭。為入學之本，十二字頭熟，後讀連字無弊及讀檔案 上人名姓氏，則無滯矣。抑內中有鼻音音 $[s i c]$ 、喉音、齒音、直舌音、閉口音、卷舌音、撮口音。其滾舌 音最要熟練。初學者務將漢字傍釋從京韻對註。凡本字之音，不能對者，字角上加一小圈，以別平上去入 之要; 庶無多錯之病爾。」

50. Ibid., shier zitou, 1b-2a, where luo 洛 without a drop spells lo and the same character with a drop spells ro. 
Although it remains unclear whether some of the differences between the two prefaces were due to deliberate innovation or merely constituted differences in wording, it is nevertheless clear that the preface to Jianzhu shier zitou is derived in its entirety from Shier zitou jizhu. This in turn suggests that Shen Qiliang might not have been involved at all in the production of the former. By 1701, Shen might have become a famous name in Manchu language-studies circles, compelling a commercial publisher to borrow his name for a publication in which he had no part. Since there is no evidence that Shen was alive after 1693, when he wrote the highly autobiographical preface to Yuzhi baijia xing Man-Han heji, he might even have quietly passed from the scene by that time.

Echoes of Shier zitou jizhu can be seen in the later history of the Manchu syllabary. In 1733, the preface to Hi Hiya's 奚霞 (n.d.) version of Jianzhu shier zitou included the by now familiar assertion that "in [the syllabary] there are nasal sounds, anterior dental sounds, trilled sounds, throat sounds, sounds with a straight tongue, as well as closedmouth, rolled-tongue, and pinched-mouth sounds." ${ }^{51}$ In 1861, Hi Hiya's version was reprinted with the same preface in an edition that had evidently been put together using blocks from two separate earlier editions, indicating that the syllabary carrying Shen's phonological description might have been produced in more editions than we know at present. ${ }^{52}$ The 1861 edition carried the echoes of Shen's 1686 preface into the second half of the nineteenth century. Through several publications, whose paratexts and physical appearance reveal them as commercial prints, Shen's categorization of Manchu pronunciation using a terminology borrowed from the discipline of phonology survived to reach generations of readers unaware of its origins in Shier zitou jizhu.

51. Hi Hiya, annot., Man-Han quanzi shier tou 滿漢全字十二頭 Man Han ciyun dz si el teo (The twelve heads in complete Manchu and Chinese characters), xylograph (Beijing: Hongwen ge, 1733), 1b: 內有鼻音、齒 音、滾舌音、喉音、直 舌音、閉口、捲舌、撮口音。Huang Runhua 黃潤華, ed., Guojia tushuguan cang Manwen wenxian tulu 國家圖書 館藏滿文文獻圖錄 (Illustrated record of Manchu documents in the holdings of the National Library of China) (Beijing: Guojia tushuguan chubanshe, 2010), p. 17, shows a photo of this edition's cover page. It is also described in Zhongguo kexueyuan tushuguan, Хuxiu Sikuquanshu zongmu tiyao (gaoben), 6: 48, where it is erroneously said to be the earliest printing of the syllabary as a separate work. Matsumura Jun 松村潤, Beikoku gikai toshokan shozō Manshūgo bunken mokuroku 米國議會圖書館所藏滿洲語文獻目錄 (A catalogue of Manchu materials in the Library of Congress) (Tōkyō: Tōhoku Ajia bunken kenkyūkai, 1999), p. 22, lists an edition also from 1733 but printed by Zhihe tang 致和唐 in Mukden.

52. Man-Han shier zitou 滿漢十二字頭 (The twelve heads in Manchu and Chinese), xylograph, the title being the title on the cover page (Beijing: Wenxing tang, 1861), held at Peking University Library with the call number $\mathrm{x} / 419.1 / 0033,11 \mathrm{a}$, after which the running title and the pagination change, indicating the use of two different sets of blocks. The end of the book (page 9a in the new pagination) says that it was printed by Hongwen ge 宏文閣, responsible also for one of the 1733 editions. It is likely that this is the copy that was previously owned by Walter Fuchs (1902-1979), who described a copy of this edition and whose Manchu collection eventually passed into the hands of Yenching and later Peking University: Fuchs, "Neue Beiträge zur mandjurischen Bibliographie," p. 16; According to Shandong daxue tushuguan 山东大学 图书馆, Shandong daxue tushuguan guji shanben shumu 山东大学图书馆古籍善本书目 (Catalog of rare books in the Shandong University Library) (Jinan: Qi-Lu Shushe, 2007), p. 47, a copy was also owned by a Republican collector with the studio name Qilüe An 七略䀃. However, this collector's manuscript bibliography does not list the work: 中國著名藏 書家書目匯刊: 明清卷 (Collection of the bibliographies of famous Chinese book collectors: Ming-Qing part) (Beijing: Shangwu yinshuguan, 2005), 38: 463-91. 


\section{Summary}

The preceding discussion has served two purposes: (1) to introduce Shier zitou jizhu, a hitherto unstudied work by Shen Qiliang, previously known only through a lacunary and misleading catalog entry describing its only known extant copy, and (2) to relate the book to a similar later work purported to be by Shen, but which in light of new evidence was more likely produced on the basis of Shier zitou jizhu without Shen's involvement at a time when Shen might already have died. In the future, I hope to complement the present paper with a study of Shen's life and work in relation to the development of Qing grammatology and Manchu lexicography more generally.

\section{References}

An Shuangcheng 安双成. “Manwen shier zitou wo jian” 满文十二字头我见 (My views on the Manchu twelve heads). In Manzu lishi yu wenhua 满族历史与文化, edited by Wang Zhonghan 王钟 翰, pp. 233-243. Beijing: Zhongyang minzu daxue chubanshe, 1996.

Beijing shi minzu guji zhengli chuban guihua xiaozu 北京市民族古籍整理出版规划小组. Beijing diqu Manwen tushu zongmu 北京地区满文图书总目 (Comprehensive catalog of Manchu material in libraries in the Beijing area). Shenyang: Liaoning minzu chubanshe, 2008.

Chunhua 春花. “Qianlong chixiu Qinding Qing-Han duiyin zishi ji qi yingxiang” 乾隆敕修《钦定 清汉对音字式》及其影响 (Qianlong's imperially edited Qinding Qing-Han duiyin zishi and its influence). Lishi dang’an 历史档案 2008.1: 54-59.

Crossley, Pamela Kyle, and Evelyn S. Rawski. "A Profile of the Manchu Language in Ch'ing History." Harvard Journal of Asiatic Studies 53.1 (1993): 63-102. http://dx.doi.org/10.2307/2719468

Elliott, Mark C., and James Bosson. "Highlights of the Manchu-Mongolian Collection." In Treasures of the Yenching: Seventy-Fifth Anniversary of the Harvard-Yenching Library, edited by Patrick Hanan, pp. 79-121. Cambridge, Mass.: Harvard-Yenching Library, Harvard University, 2003.

Fuchs, Walter. Beiträge zur mandjurischen Bibliographie und Literatur. Tōkyō: Deutsche Gesellschaft für Natur- und Volkerkunde Ostasiens, 1936.

"Miszellen zu Mandjurisch-Chinesischen Drucken." Zentralasiatische Studien 5 (1971): $121-26$.

"Neue Beiträge zur mandjurischen Bibliographie und Literatur." Monumenta Serica 7.1-2 (1942): 1-37.

"Neues Material zur mandjurischen Literatur aus Pekinger Bibliotheken." Asia Major 7 (1932): 469-82.

Geng Zhensheng 耿振生. Ming-Qing dengyun xue tonglun 明清等韵学通论 (Comprehensive discussion of Ming-Qing rhyme table learning). Beijing: Yuwen chubanshe, 1992.

Hasse, Adelaide R. Index to United States Documents Relating to Foreign Affairs, 1828-1861, in Three Parts, Part III - R to Z. Washington, D.C.: Carnegie Institution of Washington, 1921.

Hayata Teruhiro 早田輝洋 and Teramura Masao 寺村政男, eds. Daishin zensho: Zōho kaitei, tsuketari Manshügo, Kango sakuin 大清全書: 増補改訂 · 附満洲語漢語索引 (Expanded and emended edition of Da-Qing quanshu, with appended Manchu and Chinese indexes). 3 vols. Fuchū: Tōkyō gaikokugo daigaku Ajia Afurika gengo bunka kenkyū jo, 2004. 
Hi Hiya 谿霞, annot. Man-Han quanzi shier tou 滿漢全字十二頭 Man Han ciyun dz si el teo (The twelve heads in complete Manchu and Chinese characters). Xylograph. Beijing: Hongwen ge, 1733.

Huang Runhua 黄润华. “Manwen fangke tushu shulun” 满文坊刻图书述论 (Account of commercial publishing in Manchu). Wenxian 文献 1999.2: 220-35.

黃潤華, ed. Guojia tushuguan cang Manwen wenxian tulu 國家圖書館藏滿文文獻圖錄 (Illustrated record of Manchu documents in the holdings of the National Library of China). Beijing: Guojia tushuguan chubanshe, 2010.

and $\mathrm{Qu}$ Liusheng 屈六生, eds. Quanguo Manwen tushu ziliao lianhe mulu 全国满文图书 资料联合目录 (Union catalog of Manchu material nationwide). Beijing: Shumu wenxian chubanshe, 1991.

Ikegami Jirō 池上二郎. “Yōroppa ni aru Manshūgo bunken ni tsuite”ヨーロッパにある満洲語文 献について (On Manchu documents in Europe). Tōyō gakuhō 東洋学報 45.3 (1962): 105-21.

“Yōroppa ni aru Manshūgo bunken ni tsuite (hoi)”ヨーロッパにある満洲語文献に ついて (補遺) (On Manchu documents in Europe [supplement]). Tōyō gakuhō 東洋学報 47.3 (1964): 144-46.

Juwan juwe uju bithe (The book of the twelve heads). Chirograph. Held at the Harvard-Yenching Library with the call number MA 5806.024130 .

Kanda Nobuo 神田信夫. “Ōbei genson no Manshūgo bunken” 欧米現存の満洲語文献 (Manchu documents currently held in European and American libraries). Tōyo gakuhō 東洋学報 48.2 (1965): 70-95.

. "Present State of Preservation of Manchu Literature." Memoirs of the Research Department of the Toyo Bunko 26 (1968): 63-95.

. "Shen Ch'i-liang and His Works on the Manchu Language." In Proceedings of the Third East Asian Altaistic Conference, edited by Ch'en Chieh-hsien and Sechin Jagchid, pp. 129-43. Taibei: The Third East Asian Altaistic Conference, 1969.

Katō Naoto 加藤直人. “Roshia no Manshūgo shiryō” ロシアの満洲語資料 (Manchu material in Russia). Manzokushi kenkyū tsūshin 満族史研究通信 6 (1997): 45-62.

Lao Naixuan 勞乃宣. Dengyun yide 等韻一得 (Quick introduction to graded rhymes). Xylograph. 2 vols. Juzhai suoxue. Wuqiao guanxie, 1898.

Li Deqi 李德啓, ed. Guoli Beiping tushuguan, Gugong bowuyuan tushuguan Manwen shuji lianhe mulu 國立北平圖書館、故宮博物院圖書館滿文書籍聯合目錄 (Union catalog of Manchu books in National Beiping Library and the National Palace Museum Library). Beijing: Guoli Beiping tushuguan ji Gugong bowuyuan tushuguan, 1933.

Liao Lunji 廖綸㙨. Shier zitou 十二字頭 (The twelve character heads). In Zhengzi tong 正字通. Facsimile of xylograph. 1671. Beijing: Zhongguo gongren chubanshe, 1996.

Ligeti, Louis [Lajos]. "À propos de l'écriture mandchoue." Acta Orientalia Academia Scientarum Hungarica 2 (1952): 235-302.

Ling Shaowen 凌紹雯 and Chen Kechen 陳可臣, eds. Xinke Qingshu quanji 新刻清書全集 Ice foloho manju-i geren bithe (Complete collection of Manchu writing, newly cut). Xylograph. Nanjing: Tingsong lou, 1699. Copy held at Harvard-Yenching Library.

Man-Han shier zitou 滿漢十二字頭 (The twelve heads in Manchu and Chinese). Xylograph, the title being the title on the cover page. Beijing: Wenxing tang, 1861. Held at Peking University Library with the call number $\mathrm{x} / 419.1 / 0033$. This copy was previously owned by Walter Fuchs.

Man-Han ziyin lianzhu shiwen 滿漢字音聯註釋文 (Character pronunciations, linked annotations, and textual explanations in Manchu and Chinese). Chirograph held at Dalian Library with the call number M22-149, likely finished in 1861-1875. 2 vols. 
Matsumura Jun 松村潤. Beikoku gikai toshokan shozō Manshügo bunken mokuroku 米國議會圖書 館所藏滿洲語文獻目錄 (A catalogue of Manchu materials in the Library of Congress). Tōkyō: Tōhoku Ajia bunken kenkyūkai, 1999.

Pang, Tatiana A., and M. P. Volkova. Descriptive Catalogue of Manchu Manuscripts and Block-Prints in the St. Petersburg Branch of the Institute of Oriental Studies, Russian Academy of Sciences, Issue 2. Wiesbaden: Harrassowitz, 2001.

Plaks, Andrew H., trans. Ta Hsüeh and Chung-yung: The Highest Order of Cultivation and On the Practice of the Mean. London: Penguin, 2003.

Rawski, Evelyn S. "Qing Publishing in Non-Han Languages." In Printing and Book Culture in Late Imperial China, edited by Cynthia J. Brokaw and Kai-wing Chow, pp. 304-31. Berkeley: University of California Press, 2005. http://dx.doi.org/10.1525/california/9780520231269.003.0008

Shandong daxue tushuguan 山东大学图书馆. Shandong daxue tushuguan guji shanben shumu 山东 大学图书馆古籍善本书目 (Catalog of rare books in the Shandong University Library). Jinan: Qi-Lu Shushe, 2007.

Shen Qiliang 沈啟亮. Da-Qing quanshu 大清全書 Daicing gurun-i yooni bithe (Complete book of the Great Qing). Facsimile of xylograph. 1683. Shenyang: Liaoning minzu chubanshe, 2008. Jianzhu shier zitou 箋註十二字頭 Giyan ju si el dz teo (The twelve heads annotated). Xylograph. Beijing: Fukui zhai, 1701. Incomplete copy held at the Vatican Apostolic Library with the call number BORG. CINESE 351.7 . . Shier zitou jizhu 十二字頭集註 (Collected notes on the twelve heads). Xylograph. Chongli tang, 1686. Held at the library of the National Museum of China.

, ed. Qingshu zhinan 清書指南 Manju gisun-i jyî nan (Guide to Qing writing). Xylograph. 1682. 1713. Extant only as a supplement to the 2nd edition of Da-Qing quanshu (it carries no publication data of its own). Microfilmed copy held at Tenri University Library.

Stary, Giovanni. Opere mancesi in Italia e in Vaticano (Manchu works in Italy and the Vatican). Wiesbaden: Harrassowitz, 1985.

[Verbiest, Ferdinand]. Elementa lingue tartarice (Rudiments of the Tartar language). Edited by Melchisédech Thévenot. Written 1677-1678 and edited 1686. Paris: Thomas Moette, 1696. Fourteen years passed between printing and publishing.

Walravens, Hartmut, ed. Mandjurische Bücher in Rußland: Drei Bestandskataloge. Hamburg: C. Bell Verlag, 1986.

Xiong Shibo 熊士伯, Dengqie yuansheng 等切元聲 (The fundamental sounds cut in grades), facsimile of xylograph, Siku quanshu cunmu congshu: jingbu vol. 219 (1709; Jinan: Qi-Lu shushe, 1997), partially illegible.

Yao Xiaoping 姚小平. “Fandigang tushuguan suocang ruogan Ming-Qing yuyan wenzi shu” 梵蒂冈 图书馆所藏若干明清语言文字书 (Some Ming-Qing books on language and writing held in the Vatican Library). Yuyan kexue 语言科学 5.6 (2006): 96-105.

Zhang Zhigong 张志公. Chuantong yuwen jiaoyu chutan ( fu mengxue shumu gao) 传統语文教育初探 (附蒙学书目稿) (First forays in traditional literacy education [with a draft bibliography of primers appended]). Shanghai: Shanghai jiaoyu chubanshe, 1962.

Zhongguo kexueyuan tushuguan 中國科學院圖書館, ed. Xuxiu Siku quanshu zongmu tiyao (gaoben) 續修四庫全書總目提要 (稿本) (Bibliographical summary of the Sequel to the Complete books of the four repositories [draft edition]). Facsimiles of manuscripts by multiple authors. 38 vols. Jinan: Qi-Lu Shushe, 1996. Written during 1931-1942. Volumes 5-7 contain bibliographical précis of Manchu and Mongolian books written by Fengkuan 奉寬 (1876-1943). Neither the books nor the précis were included in the Xuxiu Siku quanshu as eventually published. 
Zhongguo zhuming cangshu jia shumu huikan: Ming-Qing juan 中國著名藏書家書目匯刊: 明清卷 (Collection of the bibliographies of famous Chinese book collectors: Ming-Qing part). Facsimiles. 40 vols. Beijing: Shangwu yinshuguan, 2005.

Zhu Kongyang 朱孔陽. Xinke Ruizhang xuan dingzheng ziyun hebi 新刻瑞樟軒訂正字韻合璧 (Newly cut joint-faced character rhymes corrected in the Auspicious Camphorwood Studio). Facsimile of the xylograph held at the Hunan Provincial Library. Siku quanshu cunmu congshu: jingbu, vol. 199. 1628. Jinan: Qi-Lu Shushe, 1997. 